\title{
ORGANISATIONAL TRUST AS A MEDIATOR BETWEEN PERCEIVED ORGANISATIONAL SUPPORT AND CONSTRUCTIVE DEVIANCE
}

\author{
Kabiru Maitama Kura \\ Federal Polytechnic Kaura-Namoda \\ Faridahwati Mohd. Shamsudin \\ Universiti Utara Malaysia \\ Ajay Chauhan \\ Universiti Utara Malaysia
}

\begin{abstract}
Although extant empirical research on workplace deviance has traditionally focused on behaviours that threaten the well-being of an organization and/or its members, however, there is a paucity of research investigating constructive deviant behaviours, which play a significant role in creating positive organizational change. Drawing upon social exchange theory, this study examined organisational trust as a mediator of the relationship between perceived organisational support and constructive deviance. The data was obtained from a sample of 212 full-time employees of a public sector organization in Nigeria. Results from partial least square structural equation modeling (PLS-SEM) analyses revealed that perceived organisational support was positively related to constructive deviance. In addition, the results demonstrated that organisational trust partially mediated the relationship between perceived organisational support and constructive deviance.
\end{abstract}

Keywords: Constructive Deviance; Workplace Deviance; Organisational Support; Organisational Trust; Social Exchange Theory.

\section{INTRODUCTION}

Initial research has traditionally described deviant workplace behaviours (DWBs) as destructive behaviours that threaten the well-being of an organization, and/or its members (Bennett \& Robinson, 2000; Robinson \& Bennett, 1995). Specifically, early researchers often described DWBs as being similar to counterproductive work behaviour (Fox, Spector, \& Miles, 2001), dysfunctional behaviour (Griffin, O'Leary-Kelly, \& Collins, 1998), bad behaviour in organizations (Griffin \& Lopez, 2005), non-complaint behaviour, and so on (Puffer, 1987). Furthermore, DWBs have been associated with negative antecedents, including organizational injustice (Ambrose, Seabright, \& Schminke, 2002), negative affectivity (Aquino, Grover, Bradfield, \& Allen, 1999), psychological contract breach (Bordia, Restubog, \& Tang, 2008),

* Corresponding author: Department of Business Administration and Management, Federal Polytechnic Kaura-Namoda, Gusau Road 882231, Kaura-Namoda, Zamfara State, Nigeria, Email: kmkura@gmail.com 
work stressors (Chen \& Spector, 1992), abusive supervision, and so forth (Mitchell \& Ambrose, 2007). Previous research has also demonstrated that DWBs could have significant negative consequences for both organization and its members, including work-related stress (Henle, Giacalone, \& Jurkiewicz, 2005), decreased productivity (Martin \& Hine, 2005), damaged organization's reputation (Bowling \& Gruys, 2010), and decreased profitability (Lee \& Ok, 2014).

While prior research has increased our understanding of the negative consequences of deviance within organizations (i.e., destructive deviance), however, in recent years, there is a growing interest in constructive deviance. The interest in constructive deviance has grown because such behaviours can play a significant role in creating positive organizational change (Luthans \& Church, 2002; Robbins \& Galperin, 2010). Constructive deviance is defined as a "voluntary behavior that violates significant organizational norms and in doing so contributes to the wellbeing of an organization, its members, or both" (Galperin, 2003, p. 158). Examples of such behaviours include among others: departing from the organisational norms to solve problems and using unconventional ways to achieve work goals (Galperin, 2002; Galperin, 2003, 2012).

Due to the increasing interest in constructive deviance among researchers, to date, several factors have been suggested to explain the underlying cause of constructive deviance. For instance, empirical evidence suggests that perceived organizational support (POS) play an important role in promoting constructive deviance (e.g., Chen, Eisenberger, Johnson, Sucharski, \& Aselage, 2009; Eisenberger, Armeli, Rexwinkel, Lynch, \& Rhoades, 2001; Farmer, Tierney, \& Kung-McIntyre, 2003; Tucker, Chmiel, Turner, Hershcovis, \& Stride, 2008). These studies proposed social exchange perspective whereby employees exhibit constructive deviant behaviours to reciprocate the extent to which an organization values their contributions (Blau, 1964; Eisenberger, Huntington, Hutchison, \& Sowa, 1986; Moorman, Blakely, \& Niehoff, 1998)

Despite these empirical studies on the role of perceived organisational support in explaining the likelihood employees to engage in constructive deviance, however, less attention has been paid to the fundamental reason why perceived organisational support lead to constructive deviance at work. We argued that organisational trust (OT), defined as "willingness to be vulnerable" (Baumeister \& Heatherton, 1996, p. 347)may be a key mechanism in explaining constructive deviance because organisational trust has been established to be a significant predictor of both positive and negative deviant behaviours at work (Demir, 2011; Erkutlu \& Chafra, 2013; Rahim \& Nasurdin, 2008). The logic here is that trust in organisation is the fundamental reason why perceived organisational support predicts constructive deviance at work. This line of argument is consistent with social exchange principle (Blau, 1964) and Eisenberger, Fasolo, and Davis-LaMastro's(1990) who noted that 'perceived support would create trust that the organization will fulfil its exchange obligations of noticing and rewarding employee efforts made on its behalf' (p. 57). Consequently, this perception of support may prompt the employees to reciprocate by exhibiting constructive deviance at work (Moorman et al., 1998).

The purpose of this study was to examine the mediating role of trust in the relationship between perceived organisational support and constructive deviance in Nigerian public sector. To this 
end, the reminder of this paper is organized as follows. In the next section, we reviewed related literature toward the development of a theoretical model that explains the mediating role of trust in the relationship between perceived organisational support and constructive deviance. Hence, these relationships was explained from social exchange perspective (Blau, 1964). Next, using Partial Least Squares Structural Equation Modeling (PLS-SEM), we included a sample of full-time employees of a public sector organization in Nigeria to test our theoretical model. Finally, we discuss theoretical and practical implications of the findings and suggestions for future research are offered.

\section{LITERATURE REVIEW}

\subsection{Constructive deviance}

The term 'constructive deviance' was first conceptualized and validated by Galperin(2002). While constructive deviance has gained a lot of momentum in recent years, conceptual clarity still needs improvement through a more rigorous construct validity tests (Park, Song, Yoon, $\&$ Kim, 2013). There are different types of behaviours that seem to be similar to constructive deviance, including organizational citizenship behaviour (Organ, 1988, 1997), pro-social rule breaking (Moorman et al., 1998), creative performance (Madjar, Oldham, \& Pratt, 2002), whistle-blowing (Miceli \& Near, 1988; Near \& Miceli, 2013; Near \& Miceli, 1985) and prosocial behaviours, among others (O'Reilly \& Chatman, 1986; Puffer, 1987). Although different terminologies are used, using different theoretical perspectives, organizational behaviour researchers apparently agree that such behaviour could create positive organizational change (Galperin, 2003; Galperin \& Burke, 2006; Robbins \& Galperin, 2010; Vadera, Pratt, \& Mishra, 2013).

A comprehensive review of literature indicate that constructive deviance is a multidimensional construct, composed of two underlying dimensions - organisational constructive deviance and interpersonal constructive deviance (Bodankin \& Tziner, 2009) Organisational constructive deviance refers to behaviour directed at the organization, which further comprises two types of behaviours, namely; innovative behaviours aimed at helping the organization and behaviours that challenge existing norms in order to help the organization (Bodankin \& Tziner, 2009). On the other hand, interpersonal constructive deviance refers to the behaviour that is "directed at individuals and comprises behaviors such as disobeying managerial orders in order to improve organizational processes" (Tziner, Bar-Hen, Fein, Sharoni, \& Nord, 2010, p. 96 )

Previous research has linked one or more of these dimensions of constructive deviance to several factors (i.e., antecedents of CD). To date, some of the factors that have been considered include: (1) individual characteristics, such as proactive personality, extraversion and creative self-efficacy; (2) task characteristics, such as feedback style and professional identity; (3) leadership behaviours, such as transformational leadership and ethical leadership; and (4) organisational factors, including formal organizational policies, organizational justice and perceived organizational support, among others. Eisenbergeret al. (1990) suggested that constructive deviance may be strongly influenced by perceived organizational support. 


\subsection{Perceived organizational support and constructive deviance}

Perceived organizational support refers to employees' "global beliefs concerning the extent to which the organization values their contributions and cares about their well-being" (Eisenberger et al., 1986, p. 501). Eisenbergeret al. (1990) suggested that employee's perception of organizational support may play a vital role in determining work attitude benefiting the organization. This work attitude can be translated into creating constructive deviant behaviours at work as well as high organizational trust by employee (Chen et al., 2009; Eisenberger et al., 2001; Farmer et al., 2003; Tucker et al., 2008). For example, Chen et al. (2009)reported perceived organizational support is positively related to the constructive deviance, defined as temporal change in extra-role performance. In the same vein, a study conducted by Adebayo (2005) showed that perceived organizational support had positive correlation with pro-social behaviour among a sample of 163 Nigeria police officers. Recent research has also supported a robust relationship between perceived organizational support and organizational trust (e.g., Cheryani, Shahtalebi, \& Rahmanimanesh, 2012; Chiang, Han, \& Chuang, 2011; Narang \& Singh, 2012). Specifically, Chiang et al.(2011) found that perceived organizational support has a significant positive relationship with organizational trust. Similarly, Narang and Singh found that (2012) perceived organizational support was positively associated with trust in the organization. Cheryani et al's (2012)empirical study showed a significant a significant positive relationship between perceived organizational support and organizational trust among high school teachers in Isfahan, Iran. On the basis of these empirical evidences, the following hypothesis is advanced:

Hypothesis 1: Perceived organizational support will be positively related to constructive deviance.

\subsection{Organizational trust as a potential mediator}

Organisational trust refers to the "willingness of a party to be vulnerable to the actions of another party based on the expectation that the other party will perform a particular action important to the trust or irrespective of the ability to monitor or control that other party" (Vohs \& Heatherton, 2000, p. 712). Recent research has supported a robust relationship between perceived organizational support and organizational trust (e.g., Cheryani et al., 2012; Chiang et al., 2011; Narang \& Singh, 2012). Specifically, Chiang et al.(2011) found that perceived organizational support has a significant positive relationship with organizational trust. Similarly, Narang and Singh found that (2012) perceived organizational support was positively associated with trust in the organization. Cheryani et al's(2012)empirical study showed a significant a significant positive relationship between perceived organizational support and organizational trust among high school teachers in Isfahan, Iran. Research also suggests that constructive deviance is strongly related with high level of organisational trust (Eisenberg et al., 2001; Robbins \& Galperin, 2010). Empirical tests conducted by Mayer and Gavin (2005) revealed a significant positive relationship between trust in management and constructive deviance among 333 manufacturing employees in Midwestern United States. A similar research conducted by Madjar and Ortiz-Walters (2009) demonstrated that both trust in supervisors and trust in customers were significant predictors of constructive deviance (i.e., creative performance). Gao, Janssen and Shi (2011) found a significant positive relationship between leader trust and constructive deviance (conceptualized as disclosing problems and making constructive suggestions in order to do things in the right way). 
In order to better understand the fundamental reason why perceived organisational support lead to constructive deviance at work, the present study underscores the importance of examining organisational trust as a mediating variable. Given a robust relationship between perceived organisational support and organizational trust (Narang \& Singh, 2012) as well as the relationship between organizational trust constructive deviance (Mayer \& Gavin, 2005), we argued that organisational trust serve as a mediator perceived organisational support constructive deviance relationship. Thus, the following hypothesis is advanced:

Hypothesis 2: Organizational trust will mediate the relationship between perceived organizational support and constructive deviance.

Based on the previous empirical studies, we developed and tested a model in which perceived organisational support predicts organizational trust, which in turn employees' constructive deviance (Figure 1).

Figure 1: Conceptual model

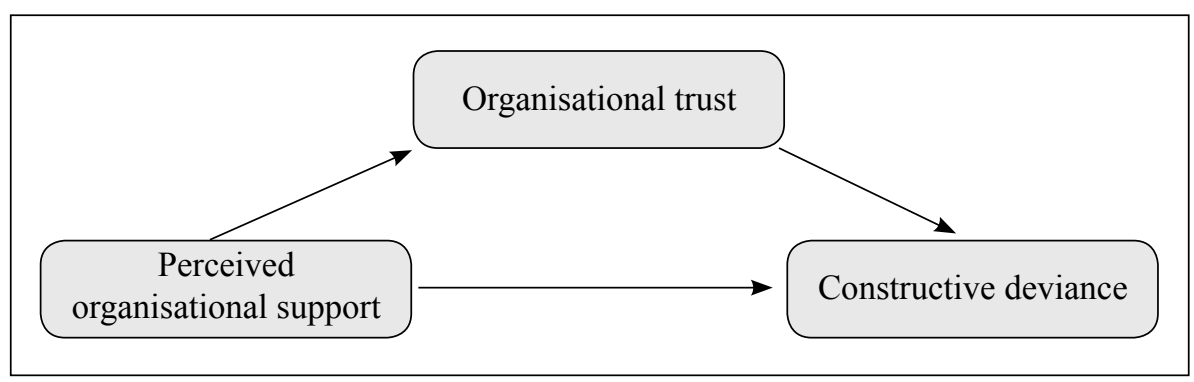

\section{METHOD}

\subsection{Sample and data collection}

Our sample consisted of 212 full-time employees from public sector organizations in Nigeria. Of 212 participants, $66 \%$ were male and $34 \%$ were female. Forty nine per cent of the participants identified themselves as Hausas, $39.2 \%$ as Yorubas, $10.4 \%$ as Igbos, $1.4 \%$ as others (minority ethnic group). The majority of respondents (i.e., 77.8\%) occupied managerial positions and the remaining $22.2 \%$ were in management positions. The mean age of participants was 39.6 years (S.D. 5.73 years) and their average job tenure was 3.17 years (S.D. .88 years).

\subsection{Measures}

\section{(a) Constructive deviance}

Although a number of constructive deviance scales have been developed to measure the underlying dimensions of constructive deviance, we have decided to use a brief measure of constructive deviance in the present study for two main reasons. Firstly, the brief measure is easy to administer, yet effective assessing the dimensions of constructive deviance (Watson, 
Clark, \& Tellegen, 1988). Secondly, brief measure helps in minimizing transient measurement errors that could arise when participants are in a negative mood, or because they respond carelessly due to frustration with the lengthy questionnaire (Donnellan, Oswald, Baird, \& Lucas, 2006). Thus, to measure constructive deviance, we specifically used Galperin's(2012) 10 -item measure of constructive deviance. All items were scored on a 5-point Likert scale (1 =never; 2 = rarely; 3 = sometimes; $4=$ often; 5 =always). Sample items are "Sought to bend or break the rules in order to perform your job" and "Reported a wrong-doing to co-workers to bring about a positive organizational change".

\section{(b) Perceived organisational support}

Perceived organizational supportwas assessed by adopting 10 highly-loaded items from Eisenbergeret al.'s (1986) 36-item measure of organizational support. All participants were requested to indicate their perceptions of the organizational support on a 5-point Likert scale ( 1 = strongly disagree; 2 = disagree; 3 = neither agree nor disagree; 4 =agree; $5=$ strongly agree). Sample items are "The organization really cares about my well-being" and "The organization shows very little concern for me (R)".

\section{(c) Organizational trust}

Cook and Wall's (1980) Organizational Trust Scale was adapted, in which 7 items were used to measure organizational trust. All items were scored on a 5-point Likert scale $(1=$ strongly disagree; 2 = disagree; 3 = neither agree nor disagree; 4 =agree; $5=$ strongly agree). Sample items are "1 feel quite confident that my organization will always try to treat me fairly" and "most of my fellow workers would get on with their work even in the absent of supervisors".

\section{(d) Control variables}

To ensure that the relationships between the antecedents and organisational deviance are not confounded, we controlled for the demographic variables of age (continuous variable), tenure (continuous variable), gender was assessed with a dummy variable $(1=$ male $)$, and ethnicity $(1$ =Yoruba; 2 = Hausa; 3 =Igbo; 4 = Others). Specifically, ethnicity was measured with three dummy variables, with Yoruba as the reference category.

\subsection{Analytical approach}

We employed partial least squares (PLS) path modeling(Wold, 1974, 1985) using SmartPLS 2.0 M3 software (Ringle, Wende, \& Will, 2005) to test the theoretical model in the present study. The PLS path modeling is considered as the most suitable technique in this study for the following. Firstly, PLS path modeling has the advantage of estimating the relationships between constructs (structural model) and relationships between indicators and their corresponding latent constructs (measurement model) simultaneously (Chin, Marcolin, \& Newsted, 2003; Spector \& Jex, 1998). Finally, compared to other path modeling software (e.g., AMOS; Analysis of Moment Structures), the Smart PLS 2.0 M3 software was selected as a tool of analysis because of its friendly graphical user interface, which help users test a mediating effect using Preacher and Hayes $(2008 ; 2004)$ bootstrapping techniques of estimating indirect effects in simple mediation models. 


\section{RESULTS}

\subsection{Measurement model}

To assess the psychometric properties of the scales, individual item reliability, internal consistency reliability, convergent validity, and discriminant validity were ascertained in the present study (Henseler, Ringle, \& Sinkovics, 2009) as presented in Table 1. Regarding the individual item reliability, outer loadings below .50 were deleted from the PLS measurement model as recommended by Barclay, Thompson, and Higgins (1995).Following this rule of thumb, of the 27 items in our reflective measurement model, only 9 were deleted. Hence, 18 items with loadings between .538 and 0.933 were retained (Table 1).The internal consistency reliability was assessed using composite reliability coefficient (Hair, Sarstedt, Ringle, \& Mena, 2012). As shown in Table 1, the composite reliability coefficient of each latent constructs ranged from .869 to .905 , exceeding the minimum acceptable level of .70 as suggested by Bagozzi and Yi (1988). Thus, based on composite reliability coefficients reported in this study (Table 1), it can be concluded that adequate internal consistency reliability was established (Hair et al., 2012). Convergent validity was assessed by examining the Average Variance Extracted (AVE) for each latent construct (Fornell \& Larcker, 1981). According to Chin (1998) the AVE for each latent construct should be .50 or more. Following Chin's (1998) rule of thumb for assessing convergent validity, Table 1 shows that the AVE for each latent construct was greater than .50 , indicating adequate convergent validity.

Table 1: Results of the Measurement model

\begin{tabular}{lccc}
\hline \multicolumn{1}{c}{ Constructs/indicators } & Loading & Composite reliability & AVE \\
\hline Constructive deviance & & & \\
CD01 & .798 & .905 & .520 \\
CD02 & .876 & & \\
CD04 & .538 & & \\
CD05 & .628 & & \\
CD06 & .639 & & \\
CD07 & .822 & & \\
CD08 & .826 & & \\
CD09 & .696 & & \\
CD10 & .584 & & \\
\hline Organisational support & & & \\
OS05 & .805 & & \\
OS06 & .933 & & \\
OS07 & .743 & & \\
\hline Organizational trust & & & \\
OT01 & .791 & & \\
OT02 & .786 & & \\
OT03 & .766 & & \\
OT04 & .873 & & \\
OT05 & .720 & & \\
OT06 & .549 & & \\
\hline
\end{tabular}


Finally, Fornell and Larcker's(1981) criterion was used to establish discriminant validity in the present study. To this end, the square roots of average variance extracted were compared with the correlations among the latent constructs (Fornell \& Larcker, 1981). Table 2 compares the square roots of AVE for each latent construct with the correlations among the latent constructs. As shown in Table 2, the square root of the average variances extracted were all greater than the correlations among latent constructs, thereby suggesting adequate discriminant validity (Fornell \& Larcker, 1981).

Table 2: Average Variance Extracted and correlations among latent constructs

\begin{tabular}{llccc}
\hline Construct & $\mathbf{1}$ & $\mathbf{2}$ & $\mathbf{3}$ \\
\hline 1 & Constructive deviance & .72 & & \\
2 & Organisational support & .65 & .83 & \\
3 & Organizational trust & .41 & .27 & .75 \\
\hline
\end{tabular}

Note. The square root of the average variance extracted are indicated in boldface.

\subsection{Structural model}

To assess the full PLS structural model, we followed the general recommendations for testing mediating effects as suggested by Hair, Sarstedt, Hopkins, and Kuppelwieser (2014) Hayes (2013), as well as Preacher and Hayes (2008; 2004) bootstrapping techniques of estimating indirect effects in simple mediation models. These techniques are considered in this study because they provide "higher levels of statistical power compared with the Sobel test" (Spector \& Jex, 1998, p. 223 ). Firstly, we assessed the direct relationship between perceived organisational support and constructive deviance, without including organizational trust as a mediator variable to test Hypotheses 1 . Figure 2 showed the results of the direct effect model.

Figure 2: Structural model without incorporating a mediator variable

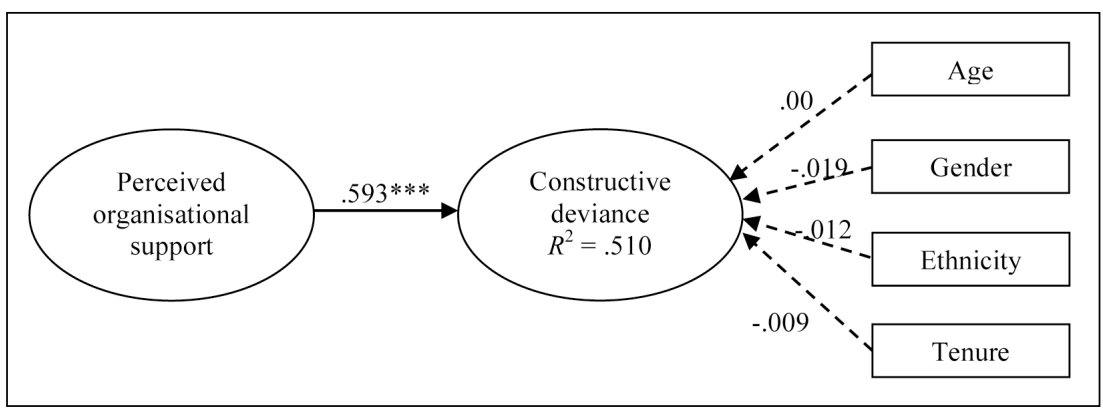

Notes: $* \mathrm{p}<.10,{ }^{* *} \mathrm{p}<.05,{ }^{* * *} \mathrm{p}<.01$ (one-tailed test); Q2 value of .234 was obtained after running the blindfolding procedure. 
The main criterion used to assess the structural model in the present study include the coefficient of determination and predictive relevance (Henseler, Ringle, \& Sarstedt, 2012). As shown in Figure 2, the research model explains $51 \%$ of the total variance in constructive deviance. To test of predictive relevance of the research model, the present study applied Stone-Geisser test of predictive relevance $\left(\mathrm{Q}^{2}\right.$; Geisser, 1974; Stone, 1974) after running the blindfolding procedure (Chin, 1998; Spector \& Jex, 1998). The $\mathrm{Q}^{2}$ value for constructive deviance was .234 (Figure 2) and also exceeded zero, thereby suggesting satisfactory predictive relevance of the model (Chin, 1998; Henseler et al., 2009). We also applied the standard bootstrapping procedure with a number of 5000 bootstrap samples and 212 cases to assess significance of the path coefficients (Henseler et al., 2012; Spector \& Jex, 1998). When the structural model was estimated without incorporating a mediator variable, the result (Figure 2) showed a significant positive relationship between perceived organizational support and constructive deviance, regardless of age, tenure, gender and ethnicity $(\beta=.593, \mathrm{p}<.01)$. As such, Hypothesis 1 was supported.

Next, we assessed the structural model with the presence of the organizational trust as a mediator variable. Figure 3 and Table 1 showed the detailed results of the full PLS path model. As shown in Figure 3 and Table 1, the coefficient of determination $\left(\mathrm{R}^{2}\right)$ was .480 , which suggests that the research model explains $48 \%$ of the total variance in constructive deviance. After running the blindfolding procedure (Chin, 1998; Spector \& Jex, 1998), the results showed that the $\mathrm{Q}^{2}$ value for constructive deviance was .217 and statistically above zero, thus, suggesting predictive relevance of the model (Chin, 1998; Henseler et al., 2009).

Figure 3: Structural model with a mediator variable incorporated

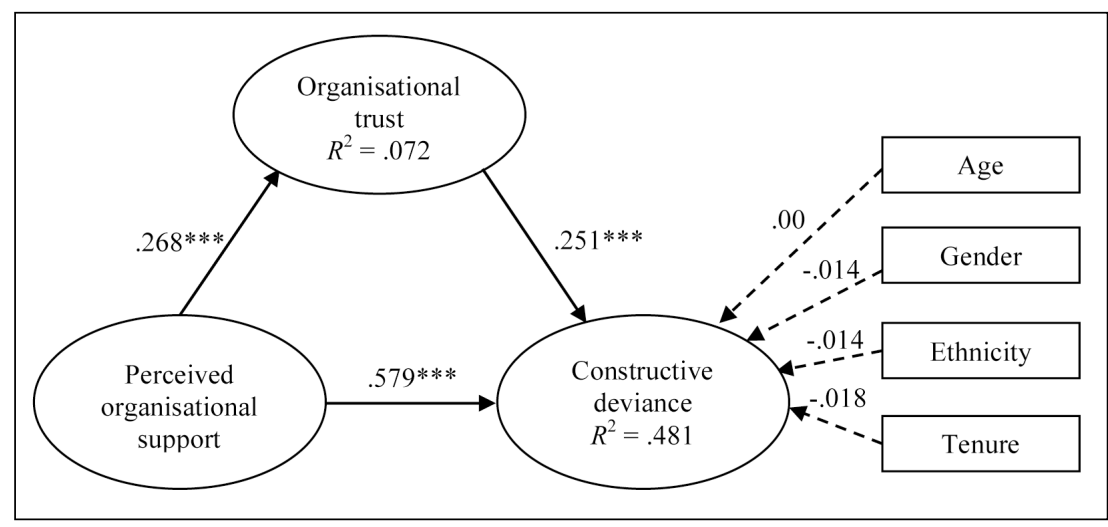

Notes: $* \mathrm{p}<.10, * * \mathrm{p}<.05, * * * \mathrm{p}<.01$ (one-tailed test); Q2 value .217 was obtained after running the blindfolding procedure. 
Furthermore, we also applied the standard bootstrapping procedure with a number of 5000 bootstrap samples and 212 cases to assess significance of the path coefficients (Henseler et al., 2012; Spector \& Jex, 1998) with a mediator variable incorporated in the PLS path model. The result (Figure 3) showed that organizational support has a significant positive relationship with organizational trust, which in turns predicted constructive deviance in a positive direction, regardless of age, tenure, gender and ethnicity. The indirect effect of perceived organizational support $(\beta=.155, \mathrm{p}<.01)$ via the mediator variable organizational trust was found to be significant, regardless of age, tenure, gender and ethnicity (Table 3). Similarly, the relationship between perceived organizational support and constructive deviance remains significant (Figure $3 ; \beta=.579, \mathrm{p}<.01$ ) but, with a difference of .014 , which is significantly lower than when organizational trust was not incorporated, even after controlling for age, tenure, gender and ethnicity (Figure $2 ; \beta=.593, \mathrm{p}<.01$ ). As such, organizational trust partially mediates the relationship between perceived organizational support and constructive deviance, after controlling for age, tenure, gender and ethnicity which lends support for Hypothesis 2 .

Table 3: Analysis of mediating effect organizational trust

\begin{tabular}{lccccc}
\hline \multirow{2}{*}{ Relation } & \multicolumn{3}{c}{ Organizational trust } & Bias corrected 95\% & VAF \\
\cline { 2 - 4 } & $\begin{array}{c}\text { Direct } \\
\text { effect }\end{array}$ & $\begin{array}{c}\text { Direct } \\
\text { effect }\end{array}$ & $\begin{array}{c}\text { Direct } \\
\text { effect }\end{array}$ & confidence interval & \\
\hline $\begin{array}{l}\text { Organisational } \\
\text { support }->\end{array}$ & $.579 * * *$ & $.155^{* * *}$ & $.734 * * *$ & {$[.492 ; .667]$} & $\begin{array}{c}79 \% \\
\text { (partial } \\
\begin{array}{l}\text { Constructive } \\
\text { deviance }\end{array}\end{array}$ \\
\hline
\end{tabular}

Notes: ${ }^{*} \mathrm{p}<.10,{ }^{* *} \mathrm{p}<.05, * * * \mathrm{p}<.01$ (one-tailed test); $\mathrm{VAF}=$ variance accounted for.

The strength of the mediating effect was determined using variance accounted for (VAF; Tol, 2002). The VAF is obtained by dividing the direct effect with total effect and should not be constrained to be between 0 and 100; and higher the value of VAF suggests stronger mediating effect (Spector \& Jex, 1998; Tol, 2002). According to Hair et al (2014) VAF $>80 \%$ suggests full mediation, $20 \% \leq \mathrm{VAF} \leq 80 \%$ indicates partial mediation and $\mathrm{VAF}<20 \%$ is an indication of no mediation. Therefore, the result (Table 1) showed that the partial mediation has a strong VAF value of $79 \%$.

\section{DISCUSSION}

Prior research established a relationship between perceived organizational support and constructive deviance. The more the employees perceived being supported their organizations the more likely they engage in constructive deviance(Chen et al., 2009; Eisenberger et al., 2001; Farmer et al., 2003; Tucker et al., 2008). The present study extended these findings by examining the mechanism through which perceived organisational support lead to constructive deviance at work. To this end, the main focus of the present research was to examine the mediating role of trust on the relationship between perceived organisational support and constructive deviance in Nigerian public sector. The present study confirms previous research 
(e.g., Chen et al., 2009; Christian \& Ellis, 2011) showing that perceived organisational support plays a significant role in explaining the likelihood of employees to engage in constructive deviance. One possible explanation for this finding is that trust in organisation is the fundamental reason why perceived organisational support exert an influence on constructive deviance at work (Cheryani et al., 2012; Chiang et al., 2011; Narang \& Singh, 2012). This line of argument is consistent with social exchange principle (Blau, 1964) and Eisenberger, Fasolo, and Davis-LaMastro's(1990) who noted that 'perceived support would create trust that the organization will fulfil its exchange obligations of noticing and rewarding employee efforts made on its behalf' (p. 57). Consequently, this perception of organizational support may prompt the employees to reciprocate by exhibiting constructive deviance at work (Moorman et al., 1998).

Furthermore, industrial and organisational psychologists have become increas $\neg$ ingly interested in the behaviours that create positive organizational change (i.e., constructive deviance; Luthans \& Church, 2002; Robbins \& Galperin, 2010). In the current study, we identified perceived organisational support as one the important constructs that plays a significant role in explaining constructive deviance at work. The present study also suggests that trust in organization is the fundamental reason why perceived organisational support lead to constructive deviance. Understanding the significant predictors of constructive deviance at work has practical implications. As noted by Eisenberger et al (1990) 'perceived support would create trust that the organization will fulfil its exchange obligations of noticing and rewarding employee efforts made on its behalf' (p. 57). Consequently, this perception of support would prompt the employees to reciprocate by exhibiting constructive deviance at work (Moorman et al., 1998). Our results suggest that management could enhance employees' perception of trust in organisation by ensuring that all contractual agreements honoured and respected before industrial actions are taken by the labour union.

While the present study provides an insight into the mechanism through which perceived organisational support is significantly related to constructive deviance at work, however, it also have a number of methodological limitations that suggest additional avenues for future research directions. Firstly, the cross-sectional nature of the present study makes it impossible for causal inferences to be made regarding the effect of perceptions of organizational support and organizational trust on constructive deviance. Hence, this study needs to be replicated using longitudinal research to allow for causal inference to be made. Secondly, the sample in the present study was drawn mainly from the public sector employees in Nigeria, which makes it impossible for generalizing these findings. Therefore, this study suggests that future research should consider including employees from private sector to increase the chances for generalizing their findings. Finally, the constructive deviance was assessed using self-report measures. It is important to note that the use of self-reports is associated with common method variance (Podsakoff, MacKenzie, Lee, \& Podsakoff, 2003) and social desirability bias (Dodaj, 2012; Podsakoff \& Organ, 1986; Randall \& Fernandes, 1991). Although this study attempts to reduce these problems by ensuring anonymity and improving scale items (Podsakoff et al., 2003; Podsakoff, MacKenzie, \& Podsakoff, 2012), however, future research should use supervisor and peer rating of constructive deviance in order to control for the common method variance and social desirability bias. 
In conclusion, the present study aimed at examining the mediating role of trust on the relationship between perceived organisational support and constructive deviance among public sector employees in Nigeria. The results suggest that perceived organizational support positively related to organizational trust, which in turns predicted constructive deviance in a positive direction. Accordingly, the present study demonstrates that the trust in organisation is the fundamental mechanism through which perceived organisational support predicts constructive deviance at work.

\section{ACKNOWLEDGMENT}

An earlier version of this article was presented at the 6th International Borneo Business Conference (IBBC) 2014, organised by the Faculty of Economics and Business, Universiti Malaysia Sarawak (UNIMAS, August 2014. This study was supported by a grant from the Tertiary Education Trust Fund (TETFund), Nigeria and a Postgraduate Incentive Grant from Universiti Utara Malaysia and. This work was carried out while the first author was a Doctoral student at the Othman Yeop Abdullah Graduate School of Business, Universiti Utara Malaysia.

\section{REFERENCES}

Adebayo, D. (2005). Ethical attitudes and prosocial behaviour in the Nigeria police: Moderator effects of perceived organizational support and public recognition. Policing: An International Journal of Police Strategies \& Management, 28(4), 684-705.

Ambrose, M. L., Seabright, M. A., \& Schminke, M. (2002). Sabotage in the workplace: The role of organizational injustice. Organizational Behavior and Human Decision Processes, 89, 947-965. doi: 10.1016/s0749-5978(02)00037-7

Aquino, K., Grover, S. L., Bradfield, M., \& Allen, D. G. (1999). The effects of negative affectivity, hierarchical status, and self-determination on workplace victimization. Academy of Management Journal, 260-272.

Bagozzi, R., \& Yi, Y. (1988). On the evaluation of structural equation models. Journal of the Academy of Marketing Science, 16, 74-94. doi: 10.1007/bf02723327

Barclay, D., Thompson, R., \& Higgins, C. (1995). The partial least squares (PLS) approach to causal modeling: Personal computer adoption and use as an illustration. Technology Studies, 2, 285-309.

Baumeister, R. F., \& Heatherton, T. F. (1996). Self-regulation failure: An overview. Psychological Inquiry, 7(1), 1-15. doi: 10.1207/s15327965pli0701_1

Bennett, R. J., \& Robinson, S. L. (2000). Development of a measure of workplace deviance. Journal of Applied Psychology, 85, 349-360. doi: 10.1037/0021-9010.85.3.349

Blau, P. M. (1964). Exchange and power in social life. New York: Transaction Publishers. 
Bodankin, M., \& Tziner, A. (2009). Constructive deviance, destructive deviance and personality: how do they interrelate. Amfiteatru Economic Journal, 11, 549-564.

Bordia, P., Restubog, S. L. D., \& Tang, R. L. (2008). When employees strike back: Investigating mediating mechanisms between psychological contract breach and workplace deviance. Journal of Applied Psychology, 93, 1104-1117. doi: 10.1037/0021-9010.93.5.1104

Bowling, N. A., \& Gruys, M. L. (2010). Overlooked issues in the conceptualization and measurement of counterproductive work behaviour. Human Resource Management Review, 20(1), 54-61. doi: 10.1016/j.hrmr.2009.03.008

Chen, P. Y., \& Spector, P. E. (1992). Relationships of work stressors with aggression, withdrawal, theft and substance use: An exploratory study. Journal of Occupational \& Organizational Psychology, 65, 177-184.

Chen, Z., Eisenberger, R., Johnson, K. M., Sucharski, I. L., \& Aselage, J. (2009). Perceived organizational support and extra-role performance: Which leads to which? Journal of Social Psychology, 149, 119-124.

Cheryani, M. Z., Shahtalebi, B., \& Rahmanimanesh, M. (2012). The Relationship between perceived organizational support and organizational trust among male high school teachers in the city Isfahan in academic years 2011-2012. Life Science Journal, 9, 4125-4130.

Chiang, H.-H., Han, T.-S., \& Chuang, J.-S. (2011). The relationship between high-commitment HRM and knowledge-sharing behavior and its mediators. International Journal of Manpower, 32, 604-622.

Chin, W. W. (1998). The partial least squares approach to structural equation modeling. In G. A. Marcoulides (Ed.), Modern Methods for Business Research (pp. 295-336). Mahwah, New Jersey: Laurence Erlbaum Associates.

Chin, W. W., Marcolin, B. L., \& Newsted, P. R. (2003). A partial least squares latent variable modeling approach for measuring interaction effects: Results from a Monte Carlo Simulation study and an electronic-mail emotion/adoption study. Information Systems Research, 14, 189-217. doi: 10.1287/isre.14.2.189.16018

Christian, M. S., \& Ellis, A. P. J. (2011). Examining the effects of sleep deprivation on workplace deviance: A self-regulatory perspective. Academy of Management Journal, 54, 913-934. doi: 10.5465/amj.2010.0179

Cook, J., \& Wall, T. (1980). New work attitude measures of trust, organizational commitment and personal need non-fulfillment. Journal of Occupational Psychology, 53(1), 39-52.

Demir, M. (2011). Effects of organizational justice, trust and commitment on employees' deviant behaviour. Anatolia, 22, 204-221. doi: 10.1080/13032917.2011.597934 
Dodaj, A. (2012). Social desirability and self-reports: Testing a content and response-style model of socially desirable responding. Europe's Journal of Psychology, 8, 651-666.

Donnellan, M. B., Oswald, F. L., Baird, B. M., \& Lucas, R. E. (2006). The Mini-IPIP Scales: Tiny-yet-effective measures of the Big Five Factors of Personality. Psychological Assessment, 18, 192-203. doi: 10.1037/1040-3590.18.2.192

Eisenberg, N., Cumberland, A., Spinrad, T. L., Fabes, R. A., Shepard, S. A., Reiser, M., . . . Guthrie, I. K. (2001). The relations of regulation and emotionality to children's externalizing and internalizing problem behaviour. Child Development, 72, 1112-1134. doi: $10.1111 / 1467-8624.00337$

Eisenberger, R., Armeli, S., Rexwinkel, B., Lynch, P. D., \& Rhoades, L. (2001). Reciprocation of perceived organizational support. Journal of Applied Psychology, 86(1), 42-51. doi: 10.1037/0021-9010.86.1.42

Eisenberger, R., Fasolo, P., \& Davis-LaMastro, V. (1990). Perceived organizational support and employee diligence, commitment, and innovation. Journal of Applied Psychology, 75, 51-59.

Eisenberger, R., Huntington, R., Hutchison, S., \& Sowa, D. (1986). Perceived organizational support. Journal of Applied Psychology, 71, 500-507. doi: 10.1037/0021-9010.71.3.500

Erkutlu, H., \& Chafra, J. (2013). Effects of trust and psychological contract violation on authentic leadership and organizational deviance. Management Research Review, 36, 828848. doi: 10.1108/MRR-06-2012-0136

Farmer, S. M., Tierney, P., \& Kung-McIntyre, K. (2003). Employee creativity in Taiwan: An application of role identity theory. Academy of Management Journal, 46, 618-630. doi: $10.2307 / 30040653$

Fornell, C., \& Larcker, D. F. (1981). Evaluating structural equation models with unobservable variables and measurement error. Journal of Marketing Research 18, 39-50.

Fox, S., Spector, P. E., \& Miles, D. (2001). Counterproductive work behaviour (CWB) in response to job stressors and organizational justice: Some mediator and moderator tests for autonomy and emotions. Journal of Vocational Behavior, 59, 291-309. doi: 10.1006/ jvbe. 2001.1803

Galperin, B. L. (2002). Determinants of deviance in the workplace: An empirical examination in Canada and Mexico. Unpublished doctoral dissertation. Concordia University, Montreal, Canada.

Galperin, B. L. (2003). Can workplace deviance be constructive. In A. Sagie, S. Stashevsky \& M. Koslowsky (Eds.), Misbehaviour and dysfunctional attitudes in organizations (pp. 154-170). Basingstoke, UK: Palgrave Macmillan. 
Galperin, B. L. (2012). Exploring the nomological network of workplace deviance: Developing and validating a measure of constructive deviance. Journal of Applied Social Psychology, 42, 2988-3025. doi: 10.1111/j.1559-1816.2012.00971.x

Galperin, B. L., \& Burke, R. J. (2006). Uncovering the relationship between workaholism and workplace destructive and constructive deviance: an exploratory study. The International Journal of Human Resource Management, 17, 331-347. doi: 10.1080/09585190500404853

Gao, L., Janssen, O., \& Shi, K. (2011). Leader trust and employee voice: The moderating role of empowering leader behaviors. The Leadership Quarterly, 22, 787-798. doi: 10.1016/j. leaqua.2011.05.015

Geisser, S. (1974). A predictive approach to the random effect model. Biometrika, 61, 101107. doi: 10.1093/biomet/61.1.101

Griffin, R. W., \& Lopez, Y. P. (2005). "Bad behaviour" in organizations: A review and typology for future research. Journal of Management, 31, 988-1005.

Griffin, R. W., O'Leary-Kelly, A. E., \& Collins, J. M. (1998). Dysfunctional work behaviours in organizations. In C. L. Cooper \& D. M. Rousseau (Eds.), Trends in organizational behaviour (Vol. 5, pp. 66-82). New York: John Wiley.

Hair, J. F., Sarstedt, M., Hopkins, L., \& Kuppelwieser, V. G. (2014). Partial least squares structural equation modeling (PLS-SEM). European Business Review, 26, 106-121. doi: doi:10.1108/EBR-10-2013-0128

Hair, J. F., Sarstedt, M., Ringle, C. M., \& Mena, J. A. (2012). An assessment of the use of partial least squares structural equation modeling in marketing research. Journal of the Academy of Marketing Science, 40, 414-433. doi: 10.1007/s11747-011-0261-6

Hayes, A. F. (2013). Introduction to mediation, moderation, and conditional process analysis: A regression-based approach. New York, NY: Guilford Press.

Henle, C. A., Giacalone, R. A., \& Jurkiewicz, C. L. (2005). The Role of Ethical Ideology in Workplace Deviance. Journal of Business Ethics, 56, 219-230.

Henseler, J., Ringle, C. M., \& Sarstedt, M. (2012). Using Partial Least Squares Path Modeling in International Advertising Research: Basic Concepts and Recent Issues. In S. Okazaki (Ed.), Handbook of Research in International Advertising (pp. 252-276). Cheltenham Edward Elgar Publishing.

Henseler, J., Ringle, C. M., \& Sinkovics, R. R. (2009). The use of partial least sSquares path modeling in international marketing. In R. R. Sinkovics \& P. N. Ghauri (Eds.), Advances in International Marketing (Vol. 20, pp. 277-320). Bingley: Emerald 
Lee, J., \& Ok, C. M. (2014). Understanding hotel employees' service sabotage: Emotional labor perspective based on conservation of resources theory. International Journal of Hospitality Management, 36, 176-187. doi: 10.1016/j.ijhm.2013.08.014

Luthans, F., \& Church, A. H. (2002). Positive organizational behavior: Developing and managing psychological strengths. Academy of Management Executive, 16, 57-72. doi: 10.5465/ame.2002.6640181

Madjar, N., \& Ortiz-Walters, R. (2009). Trust in supervisors and trust in customers: Their independent, telative, and joint effects on employee performance and creativity. Human Performance, 22, 128-142. doi: 10.1080/08959280902743501

Madjar, N., Oldham, G. R., \& Pratt, M. G. (2002). There's no place like home? The Contributions of work and nonwork creativity support to employees' creative performance. The Academy of Management Journal, 45, 757-767. doi: 10.2307/3069309

Martin, R. J., \& Hine, D. W. (2005). Development and validation of the Uncivil Workplace Behavior Questionnaire. Journal of Occupational Health Psychology, 10, 477-490. doi: 10.1037/1076-8998.10.4.477

Mayer, R. C., \& Gavin, M. B. (2005). Trust in management and performance: Who minds the shop while the employees watch the boss? Academy of Management Journal, 48(5), 874888. doi: $10.5465 / \mathrm{amj} .2005 .18803928$

Miceli, M. P., \& Near, J. P. (1988). Individual and situational correlates of whistle-blowing. Personnel Psychology, 41, 267-281. doi: 10.1111/j.1744-6570.1988.tb02385.x

Mitchell, M. S., \& Ambrose, M. L. (2007). Abusive supervision and workplace deviance and the moderating effects of negative reciprocity beliefs. Journal of Applied Psychology, 92, 1159-1168. doi: 10.1037/0021-9010.92.4.1159

Moorman, R. H., Blakely, G. L., \& Niehoff, B. P. (1998). Does perceived organizational support mediate the relationship between procedural justice and organizational citizenship behavior? [Article]. Academy of Management Journal, 41, 351-357. doi: 10.2307/256913

Narang, L., \& Singh, L. (2012). Role of perceived organizational support in the relationship between HR practices and organizational trust. Global Business Review, 13, 239-249. doi: $10.1177 / 097215091201300204$

Near, J. P., \& Miceli, M. P. (1985). Organizational dissidence: The case of whistle-blowing. Journal of Business Ethics, 4(1), 1-16.

Near, J., \& Miceli, M. (2013). Organizational dissidence: The case of whistle-blowing. In A. C. Michalos \& D. C. Poff (Eds.), Citation classics from the Journal of Business Ethics (Vol. 2, pp. 153-172). Netherlands: Springer 
O'Reilly, C. A., \& Chatman, J. (1986). Organizational commitment and psychological attachment: The effects of compliance, identification, and internalization on prosocial behaviour. Journal of Applied Psychology, 71, 492-499. doi: 10.1037/0021-9010.71.3.492

Organ, D. W. (1988). Organizational citizenship behaviour. Lexington, MA: Lexington Books.

Organ, D. W. (1997). Organizational citizenship behaviour: It's construct clean-up time. Human Performance, 10, 85-97. doi: 10.1207/s15327043hup1002_2

Park, C. H., Song, J. H., Yoon, S. W., \& Kim, J. (2013). A missing link: psychological ownership as a mediator between transformational leadership and organizational citizenship behaviour. Human Resource Development International, 16, 558-574. doi: $10.1080 / 13678868.2013 .839510$

Podsakoff, P. M., \& Organ, D. W. (1986). Self-reports in organizational research: Problems and prospects. Journal of Management, 12, 531-544. doi: 10.1177/014920638601200408

Podsakoff, P. M., MacKenzie, S. B., \& Podsakoff, N. P. (2012). Sources of method bias in social science research and recommendations on how to control it. Annual review of psychology, 63, 539-569.

Podsakoff, P. M., MacKenzie, S. B., Lee, J.-Y., \& Podsakoff, N. P. (2003). Common method biases in behavioral research: a critical review of the literature and recommended remedies. Journal of Applied Psychology, 88, 879-903.

Preacher, K. J., \& Hayes, A. (2008). Asymptotic and resampling strategies for assessing and comparing indirect effects in multiple mediator models. Behavior Research Methods, 40(3), 879-891. doi: 10.3758/brm.40.3.879

Preacher, K. J., \& Hayes, A. F. (2004). SPSS and SAS procedures for estimating indirect effects in simple mediation models. Behavior Research Methods, Instruments, \& Computers, 36, 717-731. doi: 10.3758/bf03206553

Puffer, S. M. (1987). Prosocial behaviour, noncompliant behaviour, and work performance among commission salespeople. Journal of Applied Psychology, 72, 615-621. doi: 10.1037/0021-9010.72.4.615

Rahim, A. R. A., \& Nasurdin, A. M. (2008). Trust in organizational and workplace deviant behaviour. Gadjah Mada International Journal of Business, 10, 211-235.

Randall, D. M., \& Fernandes, M. F. (1991). The social desirability response bias in ethics research. Journal of Business Ethics, 10, 805-817.

Ringle, C. M., Wende, S., \& Will, S. (2005). SmartPLS 2.0 beta: University of Hamburg, Hamburg. Retrieved March 13, 2014, from http://www.smartpls.de/forum/index.php. 
Robbins, D. L., \& Galperin, B. L. (2010). Constructive deviance: striving toward organizational change in healthcare. Journal of Management \& Marketing Research, 5, 1-11.

Robinson, S. L., \& Bennett, R. J. (1995). A typology of deviant workplace behaviors: A multidimensional scaling study. Academy of Management Journal, 38, 555-572.

Spector, P. E., \& Jex, S. M. (1998). Development of four self-report measures of job stressors and strain: Interpersonal Conflict at Work Scale, Organizational Constraints Scale, Quantitative Workload Inventory, and Physical Symptoms Inventory. Journal of Occupational Health Psychology, 3(4), 356.

Stone, M. (1974). Cross-validatory choice and assessment of statistical predictions. Journal of the Royal Statistical Society. Series B (Methodological), 36, 111-147. doi: 10.2307/2984809

Tol, R. J.(2002). Estimates of the Damage Costs ofClimateChange. Part 1:Benchmark Estimates. Environmental and Resource Economics, 21(1), 47-73. doi: 10.1023/a:1014500930521

Tucker, S., Chmiel, N., Turner, N., Hershcovis, M. S., \& Stride, C. B. (2008). Perceived organizational support for safety and employee safety voice: The mediating role of coworker support for safety. Journal of Occupational Health Psychology, 13, 319-330. doi: 10.1037/1076-8998.13.4.319

Tziner, A., Bar-Hen, P., Fein, E., Sharoni, G., \& Nord, T. (2010). Constructive deviance, leader-member exchange, and confidence in appraisal: How do they interrelate, if at all? Revista de Psicología del Trabajo y de las Organizaciones, 26(2), 95-100. doi: 10.5093/ tr2010v26n2a1

Vadera, A. K., Pratt, M. G., \& Mishra, P. (2013). Constructive deviance in organizations: Integrating and moving forward. Journal of Management. doi: 10.1177/0149206313475816

Vohs, K. D., \& Heatherton, T. F. (2000). Self-regulatory failure: A resource-depletion approach. Psychological Science, 11, 249-254. doi: 10.1111/1467-9280.00250

Watson, D., Clark, L. A., \& Tellegen, A. (1988). Development and validation of brief measures of positive and negative affect: The PANAS scales. Journal of Personality and Social Psychology, 54, 1063-1070. doi: 10.1037/0022-3514.54.6.1063

Wold, H. (1974). Causal flows with latent variables: Partings of the ways in the light of NIPALS modelling. European Economic Review, 5, 67-86. doi: 10.1016/0014-2921(74)90008-7

Wold, H. (1985). Partial least squares. In S. Kotz \& N. L. Johnson (Eds.), Encyclopedia of Statistical Sciences (Vol. 6, pp. 581-591). New York: Wiley. 